\title{
Improved performance of botia fish Chromobotia macracanthus with the utilization of blood clam shell in the recirculation system
}

\section{Peningkatan kinerja produksi ikan botia Chromobotia macracanthus dengan pemanfaatan cangkang kerang darah pada sistem resirkulasi}

\author{
Rani Ria Rizki ${ }^{1}$, Iis Diatin ${ }^{1 *}$, Tatag Budiardi ${ }^{1}$, Irzal Effendi ${ }^{1}$ \\ 'Department of Aquaculture, Faculty of Fisheries and Marine Science, IPB University, \\ Bogor, West Java, Indonesia \\ *Cooresponding author : Iisdiatin@yahoo.co.id
}

(Received March 10, 2020; Accepted May 21, 2020)

\begin{abstract}
Intermediate and holding rearing of botia face several problems such as the limited land, water quality, and decreased growth. The application of a recirculation culture system using the blood clam filter is increased to water quality and expected to solve the problems. This study aimed to analyze the production performance of botia fish on intermediate and holding rearing in the recirculation system by utilizing blood clams as the filter. This study used a factorial completely randomized design with two factors; clam particle sizes $(1 \mathrm{~mm}, 2 \mathrm{~mm}$, and $3 \mathrm{~mm})$ and dosages $(1.4 \mathrm{~g} / \mathrm{L}, 1.8 \mathrm{~g} / \mathrm{L}$, and $2.2 \mathrm{~g} / \mathrm{L})$. Every experiment was conducted in three replication. The aquarium used in this study was $40 \times 40 \times 60 \mathrm{~cm}^{3}$. The size of fish samples was $3.5 \pm 0.5 \mathrm{~cm}$ with the stocking density ( $3 \mathrm{fish} / \mathrm{L}$, each test aquarium). The recirculation system was applied seven days before the fish were stocked. Every 15 days, weight and length of fish were measured (for 60 days). The results of physical (temperature) and chemical ( $\mathrm{pH}$, dissolved oxygen, ammonia, and nitrite) water quality in the recirculation system using the blood clam filter showed good conditions for botia fish. The stress response of botia blood glucose and TKO fluctuates with environmental changes. Mineral water and fish produced by calcium, magnesium, and phosphorus increase until the end of maintenance. There is an interaction at TKH between particle size and the dose of blood shells, whereas, LMPW, LMPL, and RKP significantly different only the use of dose $2.2 \mathrm{~g} / \mathrm{L}$.
\end{abstract}

Keywords: Clamshells, botia fish, $\mathrm{pH}$ value, minerals, recirculation.

\begin{abstract}
ABSTRAK
Permasalahan pada proses penampungan ikan botia yaitu keterbatasan lahan, kualitas air yang buruk dan pertumbuhan ikan botia yang lambat. Penerapan sistem resirkulasi menggunakan cangkang darah dapat meningkatkan kualitas air dan kinerja produksi. Penelitian ini bertujuan menganalisis kinerja produksi budidaya ikan botia pada sistem resirkulasi dengan pemanfataan cangkang kerang darah sebagai bahan filter. Penelitian ini menggunakan rancangan acak lengkap faktorial dua faktor, yaitu ukuran partikel cangkang kerang darah $(1 \mathrm{~mm}, 2$ $\mathrm{mm}$, dan $3 \mathrm{~mm})$ dan dosis cangkang kerang darah $(1.4 \mathrm{~g} / \mathrm{L}, 1.8 \mathrm{~g} / \mathrm{L}$, dan $2.2 \mathrm{~g} / \mathrm{L})$. Setiap perlakuan dilakukan dengan tiga kali ulangan. Akuarium yang digunakan dalam penelitian berukuran $40 \times 40 \times 60 \mathrm{~cm}^{3}$. Ikan yang digunakan berukuran $3.5 \pm 0.5 \mathrm{~cm}$ dengan padat tebar $3 \mathrm{ekor} / \mathrm{L}$. Sistem resirkulasi dioperasikan selama tujuh hari sebelum ikan ditebar. Bobot dan panjang ikan diukur setiap 15 hari selama 60 hari pemeliharaan. Penelitian dalam sistem resirkulasi menggunakan cangkang kerang darah pada media filter menghasilkan kondisi kualitas air suhu, $\mathrm{pH}$, oksigen terlarut, amonia dan nitrit air. Respons stres ikan berupa glukosa darah dan tingkat konsumsi oksigen (TKO) berfluktuasi seiring dengan perubahan lingkungan. Mineral air dan ikan yang dihasilkan meliputi kalsium, magnesium dan fosfos meningkat hingga akhir pemeliharaan. Parameter tingkat kelangsungan hidup (TKH) memiliki interaksi antara ukuran partikel dan dosis cangkang kerang darah, sedangkan untuk laju pertumbuhan bobot mutlak (LPMB), laju pertumbuhan panjang mutlak (LPMP) dan rasio konversi pakan (RKP) berbeda nyata dengan penggunaan dosis $2.2 \mathrm{~g} / \mathrm{L}$.
\end{abstract}

Kata kunci: Cangkang kerang darah, ikan botia, pH, mineral, resirkulasi. 


\section{INTRODUCTION}

Botia fish Cromobotia macracanthus is an endemic species of freshwater ornamental fish from Cobitidae family that has limited distribution only around Kalimantan and Sumatera island (Kottelat, 2013). The fishing activity of this species reached around 20-50 million of juvenile per year (Slembrouck et al., 2012), most happened in rainy season along with the increase of water level in the river. In fishing season, the size of fish is around $0,5-6,0 \mathrm{~cm}$. Botia fish that captured in rainy season, is carried and is reared in production center located close to consumers center in several big cities (Permana et al., 2011; EKI, 2017). Yet, LIPI (2014) stated that some big cities have limited land and worst water quality causing limiting factor for botia fish culture.

The optimation of land and water quality improvement could be done through an application of resirculation system for fish culture. This system is reused the water in the container after several physical filtration, chemical filtration, and biological filtration, and is supplied dissolved oxygen in water (Bragnballe, 2015). The study about resirculation system applied for botia fish rearing has been done by Ghofur \& Harianto (2018), meanwhile the resirculation system applied for red rainbow fish has been done by Nurhidayat (2012). The production process in botia fish rearing is still suffered from other obstacle, such as the fish growth. Botia fish larvae need six to eight months until it reaches the size of 2-2.5 inch (BRBIH, 2010).

The enhancement of production process by improving the production infrastructure can be done by using blood clam Anadara granosa shell as filtration media to improve water quality (Iriany \& Anugerah, 2015; Yusuf et al., 2016). Blood clam Anadara granosa shell is a by-product contained calcium carbonate Jubaedah et al., 2017). Yusuf et al. (2016) stated that chemical compounds in clam shell are chitin, calcium carbonate, calcium hydroxyapatite, and calcium phosphate. The mineral compound such as calcium and phosphor in clam shell could increase growth and could also as an absorbent by absorb heavy metals (Iriany \& Anugerah, 2015). Furthermore, blood clam shell contain calcium for bone tissue formation process that can increase fish growth and establish required environmental condition for fish allowing to increase metabolism system and fish growth (Kadarini et al., 2015; Jubaedah et al., 2017). The use of blood clam shell in resirculation system could increase the environment condition lead to better survival rate of fish and better fish growth due to the availability of sufficient mineral in water. Thereforem blood clam shell can be used as filtration media in resirculation system to improve production performance of botia fish.

\section{MATERIALS AND METHODS}

This study held for three months started from August to November 2019 in Production Technique and Aquaculture Management Laboratorium, Aquaculture Department, Faculty of Fisheries and Marine Science, IPB University.

\section{Experimental design}

This study used factorial complete randomized design. There were two factors, such as particle size $(\mathrm{P})$ of blood clam shell consisted of three treatments $(1 \mathrm{~mm}, 2 \mathrm{~mm}$, and $3 \mathrm{~mm})$, and dosages consisted of three treatments $1,4 \mathrm{~g} / \mathrm{L}, 1,8 \mathrm{~g} / \mathrm{L}$, and $2,2 \mathrm{~g} / \mathrm{L}$ ) (Tabel 1). Each treatment was repeated three times. The treatments were according to initial study.

Table 1. The combination treatments of particle size and dosage of blood clam shell

\begin{tabular}{|c|c|c|c|}
\hline \multirow{2}{*}{$\begin{array}{c}\text { Particle } \\
\text { size }(\mathrm{mm})\end{array}$} & \multicolumn{3}{|c|}{ Dosage $(\mathrm{g} / \mathrm{L})$} \\
\hline & $\begin{array}{c}\mathrm{D} 1 \\
(1,4 \mathrm{~g} / \mathrm{L})\end{array}$ & $\begin{array}{c}\mathrm{D} 2 \\
(1,8 \mathrm{~g} / \mathrm{L})\end{array}$ & $\begin{array}{c}\text { D3 } \\
(2,2 \mathrm{~g} / \mathrm{L})\end{array}$ \\
\hline $\mathrm{P} 1(1 \mathrm{~mm})$ & P1D1 & P2D1 & P3D1 \\
\hline $\mathrm{P} 2(2 \mathrm{~mm})$ & P1D2 & P2D2 & P3D2 \\
\hline P3 $(3 \mathrm{~mm})$ & P1D3 & P2D3 & P3D3 \\
\hline
\end{tabular}

\section{Rearing container and filter media setting}

The rearing containers were 27 aquariums and each of them had size of $60 \mathrm{~cm} \times 40 \mathrm{~cm} \times 40 \mathrm{~cm}$ with water level of $20 \mathrm{~cm}$ (the total water volume was $48 \mathrm{~L}$ ). The water quality was maintained by reducing water $\mathrm{pH}$ to 4 by using $1 \% \mathrm{CH}_{3} \mathrm{COOH}$ solutions.

Blood clam shell as main filter media was dried by using an oven in temperature of $110^{\circ} \mathrm{C}$ for 24 hours. Then dried blood clam shell was mashed by using feed grinding machine and was sifted out by using a sieve with a mesh size of 6 , 8,16 , and 30 until the size particle of $1 \mathrm{~mm}, 2$ $\mathrm{mm}$, and $3 \mathrm{~mm}$ are collected (Yusuf et al., 2016). The filtration of dried blood clam shell to collect those different particle sizes were used different mesh. Each size of blood clam shell particle was wrapped up by using asahi cloth. 


\section{Resirculation system installation}

Resirculation system was build up by usig PVC pipe with diameter of 3 inch and lenghth of $10 \mathrm{~cm}$. The water pump that used for this resirculation system had $24 \mathrm{~W}$ and the aeration was placed in each side of aquarium. PVC pipe was filled with blood clam shell and was performed $50 \%$ of blood clam shell changing. In addition, in all treatments, other filter media was added (sintetic cotton sized of $20 \times 5 \mathrm{~cm}$ and 15 bioballs) into PVC pipe.

\section{Botia fish rearing}

Botia fish sized of $3.5 \pm 0.5 \mathrm{~cm}$ were stocked in each aquarium with stockinh density of $2 \mathrm{fish} / \mathrm{L}$ (SNI, 2013). Botia fish was reared for 60 days and fed with blood worm as much as three times a day $(08.00,12.00$, and $16.00 \mathrm{WIB})$ in at satiation. Then, in every 15 days, from $30 \%$ of fish biomass, the fish weight and long were measured.

\section{Parameters of observation}

The measurement of water chemical, physical, and mineral

The measurement of observed parameters were chemical $(\mathrm{pH}$, dissolved oxygen, alkalinity, hardness, ammonia, and nitrite), physical (temperature). The measurement of mineral were water (calcium, magnesium, and phosphor), and fish mineral (calcium and phosphor)

\section{The respons of stress}

The blood glucose level was measured by examining three fish of each treatments. The measurement of blood glucose level used blood glucose test kit (Gluco DR Auto AGM 4000). The number showed in the test kit was the result of blood glucose level in $\mathrm{mg} / \mathrm{dL}$. The use of glicometer that is usually conducted in human blood sample can also be used for zebra fish blood sample (Eames et al., 2010).

The measurement of oxygen consumption level was done of every 15 days of rearing. Before that, the fish did not fed in a day. Then, a jar with volume of $5 \mathrm{~L}$ was filled with water and named with a label of treatment. The $3 \mathrm{~L}$ water put into each jar of each treatment; the aeration was installed for 24 hours to maintain maximal dissolved oxygen; the measurement of dissolved oxygen conducted in the beginning of the aeration was turned off; three botia fish was weighed and put into jar; then, the measurement of dissolved oxygen conducted in every hour for four hours, afterward, this measurement result is noted as oxygen consumption level. The oxygen consumption level was calculated according to NRC method (1997) as following:

$$
\mathrm{TKO}=\frac{\mathrm{V} \times\left(\mathrm{DO}_{\mathrm{t} 0}-\mathrm{DO}_{\mathrm{tt}}\right)}{\mathrm{W} \times \mathrm{t}}
$$

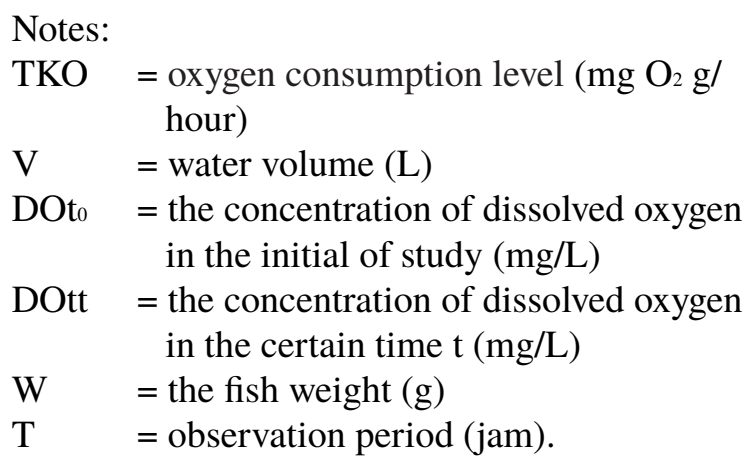

\section{Fish production performance}

The survival rate (SR) is the percentage of the ratio of survived fish in the end of the study with the total fish in the initial of study. The survival rate was calculated by using the following formula (Goddard, 1996):

$$
\mathrm{SR}=\frac{\mathrm{Nt}}{\mathrm{No}} \times 100
$$

Notes:

$\mathrm{SR}=$ The survival rate $(\%)$

$\mathrm{Nt}=$ The total survived fish in the end of study

No $=$ The total fish in the initial of study

The growth rate is the performance of average weight of each fish from the initial to an end of study. The growth rate was calculate by using this following formula (Goddard, 1996):

$$
\mathrm{GR}=\frac{\mathrm{Wt}-\mathrm{Wo}}{\mathrm{t}}
$$

Notes:

GR $=$ Growth rate $(\mathrm{g} /$ fish/day)

$\mathrm{Wt}=$ Average fish weight in the end of study (g)

Wo = Average fish weight in the initial of study (g)

$\mathrm{t}=\quad=$ Rearing period (days)

Feed conversion ratio was calculated by following formula (Goddard, 1996):

$$
\mathrm{FCR}=\frac{\mathrm{F}}{\mathrm{Wt}+\mathrm{Wo}-\mathrm{Wd}}
$$




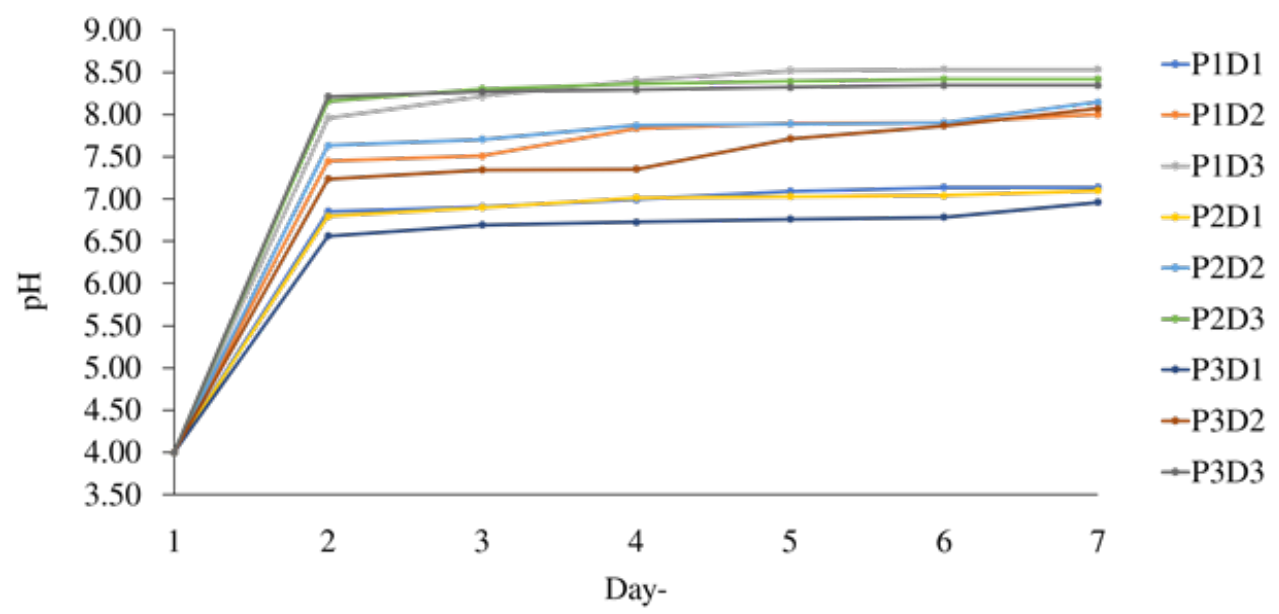

Figure 1. The water $\mathrm{pH}$ for seven days before botia fish are stocked. Note: *P1D1: the particle size was $1 \mathrm{~mm}$ and the dose was $1.4 \mathrm{~g} / \mathrm{L}$; P1D2: the particle size was $1 \mathrm{~mm}$ and the dose was $1.8 \mathrm{~g} / \mathrm{L}$; P1D3: the particle size was 1 $\mathrm{mm}$ and the dose was $2.2 \mathrm{~g} / \mathrm{L}$; P2D1: the particle size was $2 \mathrm{~mm}$ and the dose was $1.4 \mathrm{~g} / \mathrm{L}$; P2D2: the particle size was $2 \mathrm{~mm}$ and the dose was $1.8 \mathrm{~g} / \mathrm{L}$; P2D3: the particle size was $2 \mathrm{~mm}$ and the dose was $2.2 \mathrm{~g} / \mathrm{L}$; P3D1: the particle size was $3 \mathrm{~mm}$ and the dose was $1.4 \mathrm{~g} / \mathrm{L}$; P3D2: the particle size was $3 \mathrm{~mm}$ and the dose was $1.8 \mathrm{~g} / \mathrm{L}$; P3D3: the particle size was $3 \mathrm{~mm}$ and the dose was $2.2 \mathrm{~g} / \mathrm{L}$

Notes :

FCR $=$ Feed conversion ratio

$\mathrm{F} \quad=$ The total by amount of eaten fed $(\mathrm{kg})$

Wt $=$ Fish biomass in the end of study $(\mathrm{kg})$

Wd $\quad=$ Dead fish biomass during the study $(\mathrm{kg})$

W0 = Fish biomass in the the initial of study $(\mathrm{kg})$

\section{Data analysis}

The data obtained from this study was collected for further analysis. The fish production performance (SR, GR, FCR) was analyzed by using two-way ANOVA with confidence level of $95 \%$. If it showed significantly different result, the further analysis is Tukey test. The result of water mineral, fish mineral, water chemical, and water physical data was analyzed descriptively by using table and figure. The data analysis in this study used Microsoft Office Excel 2010 and SPSS 23.0 software.

\section{RESULT AND DISCUSSION}

The performance of blood clam shell as filtration media in botia fish rearing directly affected toward the change of water quality (water chemical quality). The generated environment would affect fish physiological condition (stress response), visual pigments of fish, and production performance (survival rate, growth rate, and feed consumption). The performance of blood clam shell as filtration media showed below:

\section{Water $\mathrm{pH}$ and alkalinity}

Before the botia fish are stocked, the resirculation system should be maintained already for seven days. During the intial study, the water $\mathrm{pH}$ was measured everyday for seven days, meanwhile, the water alkalinity was measured at day-1 and day-7 (Figure 1 and 2).

During the initial study for seven days, the alkalinity was $10 \mathrm{mg} . \mathrm{L}$ at day- 1 and the water $\mathrm{pH}$ was 4 in all treatments (Figure 1 and 2), then, the resirculation system was executed for maintaining the environment for botia fish, afterward, the water alkalinity and water $\mathrm{pH}$ were improved drastically, yet at day-3, the water $\mathrm{pH}$ was remained stable. The value of water alkalinity and water $\mathrm{pH}$ improvement were happen due to the $\mathrm{CaCO}_{3}$ content in blood clam shell. The calcium content in blood clam shell was $43 \%$ and the magnesium was $0.30 \%$. Meanwhile, the water alkalinity and water $\mathrm{pH}$ during botia fish rearing for 60 days was showed in Table 2 below.

The water alkalinity and water $\mathrm{pH}$ when the botia fish were stocked, was already maintained (Figure 1 and 2). The result of water alkalinity and water $\mathrm{pH}$ measurements for 60 days botia fish rearing were increased until the end of the study (Table 2), and the water hardness was also increased at the end of the study. All data were showed in Table 2 below. 


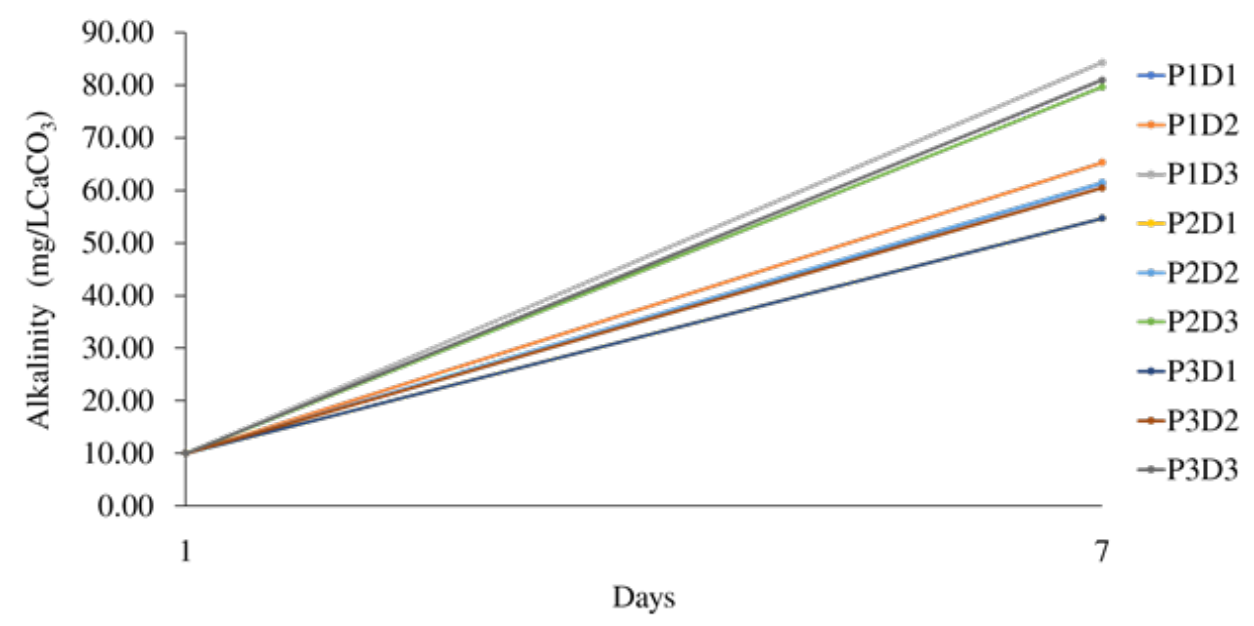

Figure 2. The water $\mathrm{pH}$ for seven days before botia fish are stocked. Note: *P1D1: the particle size was $1 \mathrm{~mm}$ and the dose was $1.4 \mathrm{~g} / \mathrm{L} ; \mathrm{P} 1 \mathrm{D} 2$ : the particle size was $1 \mathrm{~mm}$ and the dose was $1.8 \mathrm{~g} / \mathrm{L} ; \mathrm{P} 1 \mathrm{D} 3$ : the particle size was 1 $\mathrm{mm}$ and the dose was $2.2 \mathrm{~g} / \mathrm{L}$; P2D1: the particle size was $2 \mathrm{~mm}$ and the dose was $1.4 \mathrm{~g} / \mathrm{L}$; P2D2: the particle size was $2 \mathrm{~mm}$ and the dose was $1.8 \mathrm{~g} / \mathrm{L} ; \mathrm{P} 2 \mathrm{D} 3$ : the particle size was $2 \mathrm{~mm}$ and the dose was $2.2 \mathrm{~g} / \mathrm{L} ; \mathrm{P} 3 \mathrm{D} 1$ : the particle size was $3 \mathrm{~mm}$ and the dose was $1.4 \mathrm{~g} / \mathrm{L}$; P3D2: the particle size was $3 \mathrm{~mm}$ and the dose was $1.8 \mathrm{~g} / \mathrm{L}$; P3D3: the particle size was $3 \mathrm{~mm}$ and the dose was $2.2 \mathrm{~g} / \mathrm{L}$

Table 2. The water $\mathrm{pH}$, water alkalinity, and water hardness of botia fish rearing

\begin{tabular}{|c|c|c|c|c|c|c|c|c|c|}
\hline \multirow{3}{*}{ Treatments } & \multicolumn{3}{|c|}{$\mathrm{pH}$} & \multicolumn{3}{|c|}{ Alkalinity $\left(\mathrm{mg} / \mathrm{L} \mathrm{CaCO}_{3}\right)$} & \multicolumn{3}{|c|}{ Hardness $\left(\mathrm{mg} / \mathrm{L} \mathrm{CaCO}_{3}\right)$} \\
\hline & \multicolumn{9}{|c|}{ Hari ke } \\
\hline & 0 & 30 & 60 & 0 & 30 & 60 & 0 & 30 & 60 \\
\hline P1D1 & 7.1 & 5.8 & 6.2 & 61.3 & 26.9 & 32.5 & 106.7 & 174.8 & 158.8 \\
\hline P1D2 & 8.0 & 6.1 & 6.5 & 65.3 & 25.4 & 25.4 & 123.3 & 193.5 & 196.2 \\
\hline P1D3 & 8.5 & 5.8 & 6.3 & 84.3 & 22.6 & 31.1 & 151.7 & 181.5 & 241.6 \\
\hline $\mathrm{P} 2 \mathrm{D} 1$ & 7.1 & 6.0 & 6.4 & 54.7 & 25.4 & 28.3 & 96.7 & 173.5 & 186.9 \\
\hline $\mathrm{P} 2 \mathrm{D} 2$ & 8.1 & 5.8 & 6.1 & 61.5 & 19.8 & 28.3 & 123.3 & 181.5 & 206.9 \\
\hline P2D3 & 8.4 & 6.0 & 6.2 & 79.7 & 28.3 & 38.2 & 140.0 & 177.5 & 254.9 \\
\hline P3D1 & 7.0 & 5.6 & 6.0 & 54.7 & 25.4 & 18.4 & 93.3 & 133.5 & 228.2 \\
\hline P3D2 & 8.1 & 6.0 & 5.9 & 60.5 & 32.5 & 24.0 & 123.3 & 186.9 & 249.6 \\
\hline P3D3 & 8.3 & 6.2 & 6.3 & 82.3 & 24.0 & 25.4 & 140.0 & 174.8 & 230.9 \\
\hline
\end{tabular}

* Note: P1D1: the particle size was $1 \mathrm{~mm}$ and the dose was $1.4 \mathrm{~g} / \mathrm{L}$; P1D2: the particle size was $1 \mathrm{~mm}$ and the dose was $1.8 \mathrm{~g} / \mathrm{L}$; P1D3: the particle size was $1 \mathrm{~mm}$ and the dose was $2.2 \mathrm{~g} / \mathrm{L}$; P2D1: the particle size was $2 \mathrm{~mm}$ and the dose was $1.4 \mathrm{~g} / \mathrm{L}$; P2D2: the particle size was $2 \mathrm{~mm}$ and the dose was $1.8 \mathrm{~g} / \mathrm{L}$; P2D3: the particle size was $2 \mathrm{~mm}$ and the dose was $2.2 \mathrm{~g} / \mathrm{L}$; P3D1: the particle size was $3 \mathrm{~mm}$ and the dose was $1.4 \mathrm{~g} / \mathrm{L}$; P3D2: the particle size was $3 \mathrm{~mm}$ and the dose was $1.8 \mathrm{~g} / \mathrm{L}$; P3D3: the particle size was $3 \mathrm{~mm}$ and the dose was $2.2 \mathrm{~g} / \mathrm{L}$

According to the value of water $\mathrm{pH}$, water alkalinity, and water hardness for 60 days rearing, the reduction of this parameters were showed along times and after the addition of blood clam shell as filtration media, the parameters were increased. The longer of the botia fish rearing, feses waste would be produced and feed residual would be a sludge and experienced a decomposition. This kind of waste would cause the increasing of $\mathrm{CO}_{2}$ in water and water $\mathrm{pH}$ alteration. Fish respiration process would also affect $\mathrm{CO}_{2}$ level and water $\mathrm{pH}$ (Suwandi et al., 2012). Sarkar et al., (2018) stated that the water alkalinity level is an important criteria to determine suitability of water sources for fish farming. High alkalinity level can reduce $\mathrm{pH}$ fluctuation in water. The alkalinity level in water for best fish growth is between 75-200 $\mathrm{mg} / \mathrm{L}$, meanwhile, the alkalinity level in $>300$ $\mathrm{mg} / \mathrm{L}$ and $<75 \mathrm{mg} / \mathrm{L}$ can cause stress in fish. The hardness level in water was keep increased until the end of fish rearing. The increasing of hardness level in water caused by $\mathrm{Ca}$ and $\mathrm{Mg}$ compound in blood clam shell (Devi et al., 2017), hardness contains $\mathrm{Ca}^{2+}$ and $\mathrm{Mg}^{2+}$ cations $\left(\mathrm{mg} / \mathrm{L} \mathrm{CaCO}_{3}\right.$ ). 
Table 3. The value of temperature of water, ammonia, dissolved oxygen, and nitrite during 60 days of botia fish rearing

\begin{tabular}{ccccc}
\hline \multirow{2}{*}{ Treatments } & Temperature $\left({ }^{\circ} \mathrm{C}\right)$ & Ammonia $(\mathrm{mg} / \mathrm{L})$ & Dissolved oxygen $(\mathrm{mg} / \mathrm{L})$ & Nitrite $(\mathrm{mg} / \mathrm{L})$ \\
\cline { 2 - 5 } & Range of value & Rata-Average value & Average value & Average value \\
\hline P1D1 & $26.6-28.1$ & 0.001 & 6.9 & 0.27 \\
P1D2 & $26.7-27.9$ & 0.004 & 6.4 & 0.23 \\
P1D3 & $27.0-28.3$ & 0.014 & 6.4 & 0.25 \\
\hline P2D1 & $27.0-28.4$ & 0.001 & 6.9 & 0.23 \\
P2D2 & $26.7-28.3$ & 0.006 & 6.9 & 0.34 \\
P2D3 & $26.7-28.2$ & 0.006 & 6.7 & 0.43 \\
P3D1 & $26.5-28.2$ & 0.001 & 6.5 & 0.33 \\
P3D2 & $26.0-28.2$ & 0.003 & 6.6 & 0.28 \\
P3D3 & $26.5-28.8$ & 0.007 & 6.8 & 0.21 \\
\hline Reference & $24-30^{*}$ & Max. $1^{*}$ & $>3 *$ & $<1^{* *}$ \\
\hline
\end{tabular}

References: *SNI (2013); *'Deswati et al., (2018). Note: P1D1: the particle size was $1 \mathrm{~mm}$ and the dose was 1.4 $\mathrm{g} / \mathrm{L}$; P1D2: the particle size was $1 \mathrm{~mm}$ and the dose was $1.8 \mathrm{~g} / \mathrm{L}$; P1D3: the particle size was $1 \mathrm{~mm}$ and the dose was $2.2 \mathrm{~g} / \mathrm{L}$; P2D1: the particle size was $2 \mathrm{~mm}$ and the dose was $1.4 \mathrm{~g} / \mathrm{L}$; P2D2: the particle size was $2 \mathrm{~mm}$ and the dose was $1.8 \mathrm{~g} / \mathrm{L}$; P2D3: the particle size was $2 \mathrm{~mm}$ and the dose was $2.2 \mathrm{~g} / \mathrm{L} ; \mathrm{P} 3 \mathrm{D} 1$ : the particle size was 3 $\mathrm{mm}$ and the dose was $1.4 \mathrm{~g} / \mathrm{L}$; P3D2: the particle size was $3 \mathrm{~mm}$ and the dose was $1.8 \mathrm{~g} / \mathrm{L}$; P3D3: the particle size was $3 \mathrm{~mm}$ and the dose was $2.2 \mathrm{~g} / \mathrm{L}$

The hardness level in water of $0-10 \mathrm{mg} / \mathrm{L}$ or $>300$ $\mathrm{mg} / \mathrm{L}$ is unsuitable for the growth of fish larvae and fish juvenile. The temperature of water, ammonia, dissolved oxygen, and nitrite obtained during 60 days of botia fish rearing was found optimum for fish growth and fish survival rate as showed in Table 3 below.

According to the Table 3, the value of water temperature, ammonia, and dissolved oxygen during 60 days of botia fish rearing were in appropriate range (SNI, 2013) for botia fish rearing, therefore, it could support the production process of botia fish. Nitrite value that obtained during 60 days rearing was showed less than $1 \mathrm{mg} / \mathrm{L}$, which as Deswati et al., (2018) stated that this value is still in appropriate range for fish farming. Yet, the value of nitrite would keep increase as the fish rearing get longer.

\section{Mineral compound in water and fish}

According to mineral data obtained during 60 days of rearing, the calcium, phosphor, and magnesium in water were increased until day-60, so did the calcium and phosphor in fish.

The calcium compound in blood clam shell was amount $43 \%$. According to chart showed in a, c, and e (Figure 3), the calcium, phosphor, and magnesium were increased due to the soluble mineral compound in water. The increasing value of calcium and phosphor was caused by the availability of mineral produced by blood clam shell, then it can be absorbed through fish respiration process in gill and skin for bone mineralization process (Liang et al., 2018).

\section{Stress response}

The response stress parameters that measured for 15 days rearing were blood glucose evel and oxygen consumption level. The results of these measurement in all treatments were fluctuated and increased at day-30 and day-45, then reduced at day-60

Blood glucose level and oxygen consumption level that obtained during this study was reduced at day-15 and day-45. Polakof et al. (2012) stated that high glucose level can also activate glucosensor mechanism in brain areas that has been related to the control of food intake. The role of environment can also affect stress level since the fish have got stressor from the environment (Ardi et al., 2016). In a stress condition, in order to maintain the homeostatic condition that would enhance metabolic activity, fish blood glucose is increased. Moreover, Polakof et al. (2012); Bartonkova et al. (2016); Aslamyah et al. (2018) stated that fish has different stress response depending on environment condition and metabolic activity, therefore the increasing metabolism can cause available energy for growth getting less, therefore, increased metabolism can also increase oxygen consumption level. 

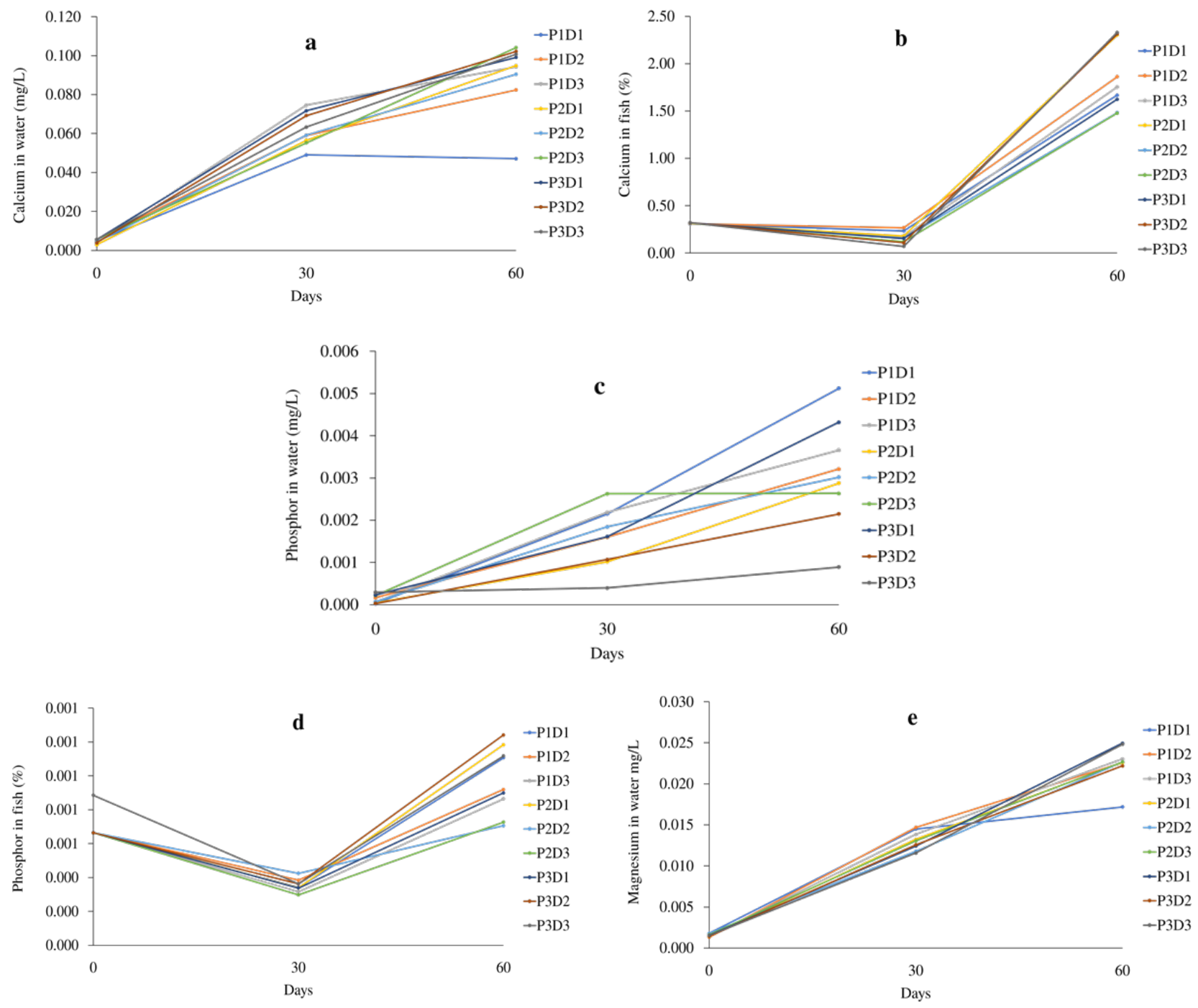

Figure 3. The result of the measurement of calcium in water (a), calcium in fish (b), phosphor in water (c), phosphor in fish (d), and magnesium in water (e) during 60 days rearing. Note: P1D1: the particle size was $1 \mathrm{~mm}$ and the dose was $1.4 \mathrm{~g} / \mathrm{L}$; P1D2: the particle size was $1 \mathrm{~mm}$ and the dose was $1.8 \mathrm{~g} / \mathrm{L}$; P1D3: the particle size was $1 \mathrm{~mm}$ and the dose was $2.2 \mathrm{~g} / \mathrm{L}$; P2D1: the particle size was $2 \mathrm{~mm}$ and the dose was $1.4 \mathrm{~g} / \mathrm{L}$; P2D2: the particle size was $2 \mathrm{~mm}$ and the dose was $1.8 \mathrm{~g} / \mathrm{L}$; P2D3: the particle size was $2 \mathrm{~mm}$ and the dose was $2.2 \mathrm{~g} / \mathrm{L}$; P3D1: the particle size was $3 \mathrm{~mm}$ and the dose was $1.4 \mathrm{~g} / \mathrm{L}$; P3D2: the particle size was $3 \mathrm{~mm}$ and the dose was $1.8 \mathrm{~g} / \mathrm{L}$; P3D3: the particle size was $3 \mathrm{~mm}$ and the dose was $2.2 \mathrm{~g} / \mathrm{L}$.

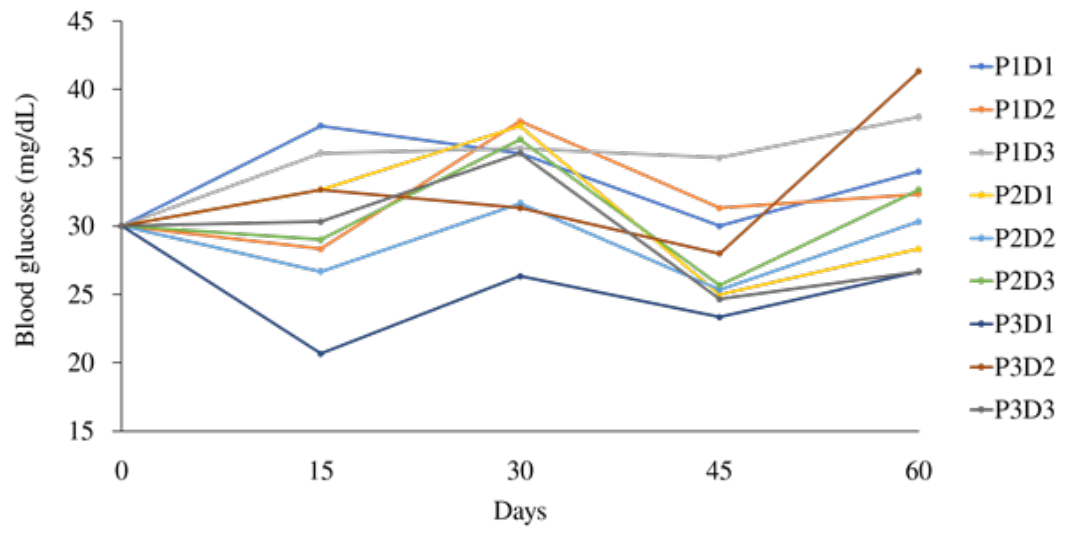

Figure 4. Blood glucose level in fish during 60 days of rearing. Note: P1D1: the particle size was $1 \mathrm{~mm}$ and the dose was $1.4 \mathrm{~g} / \mathrm{L}$; P1D2: the particle size was $1 \mathrm{~mm}$ and the dose was $1.8 \mathrm{~g} / \mathrm{L}$; P1D3: the particle size was $1 \mathrm{~mm}$ and the dose was $2.2 \mathrm{~g} / \mathrm{L}$; P2D1: the particle size was $2 \mathrm{~mm}$ and the dose was $1.4 \mathrm{~g} / \mathrm{L}$; P2D2: the particle size was $2 \mathrm{~mm}$ and the dose was $1.8 \mathrm{~g} / \mathrm{L}$; P2D3: the particle size was $2 \mathrm{~mm}$ and the dose was $2.2 \mathrm{~g} / \mathrm{L}$; P3D1: the particle size was $3 \mathrm{~mm}$ and the dose was $1.4 \mathrm{~g} / \mathrm{L}$; P3D2: the particle size was $3 \mathrm{~mm}$ and the dose was $1.8 \mathrm{~g} / \mathrm{L}$; P3D3: the particle size was $3 \mathrm{~mm}$ and the dose 


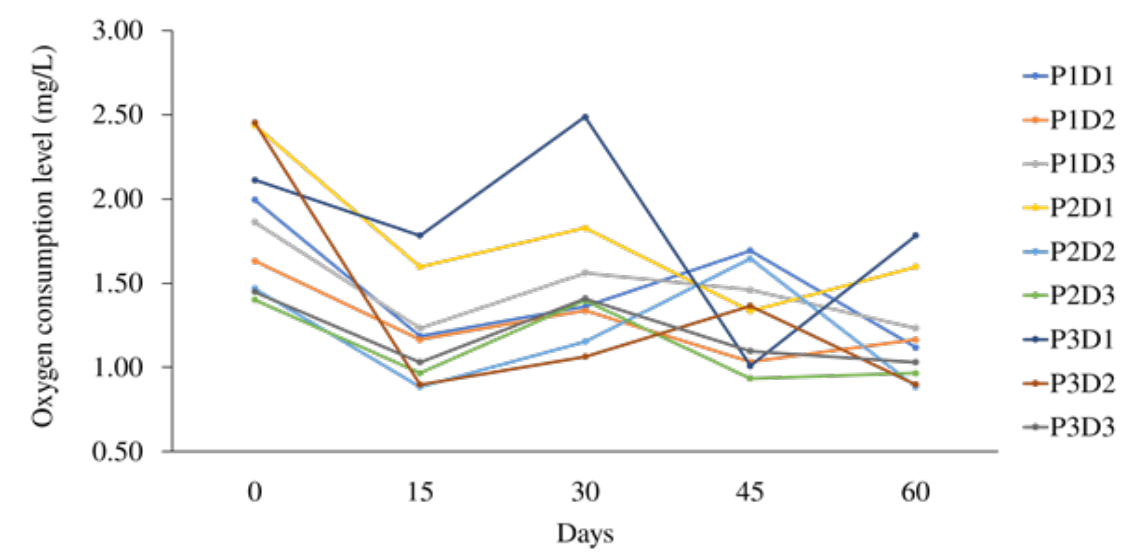

Figure 5. The oxygen consumption level during 60 days of rearing. Note: P1D1: the particle size was $1 \mathrm{~mm}$ and the dose was $1.4 \mathrm{~g} / \mathrm{L}$; P1D2: the particle size was $1 \mathrm{~mm}$ and the dose was $1.8 \mathrm{~g} / \mathrm{L}$; P1D3: the particle size was $1 \mathrm{~mm}$ and the dose was $2.2 \mathrm{~g} / \mathrm{L}$; P2D1: the particle size was $2 \mathrm{~mm}$ and the dose was $1.4 \mathrm{~g} / \mathrm{L}$; P2D2: the particle size was $2 \mathrm{~mm}$ and the dose was $1.8 \mathrm{~g} / \mathrm{L}$; P2D3: the particle size was $2 \mathrm{~mm}$ and the dose was $2.2 \mathrm{~g} / \mathrm{L}$; P3D1: the particle size was $3 \mathrm{~mm}$ and the dose was $1.4 \mathrm{~g} / \mathrm{L}$; P3D2: the particle size was $3 \mathrm{~mm}$ and the dose was $1.8 \mathrm{~g} / \mathrm{L}$; P3D3: the particle size was $3 \mathrm{~mm}$ and the dose was $2.2 \mathrm{~g} / \mathrm{L}$

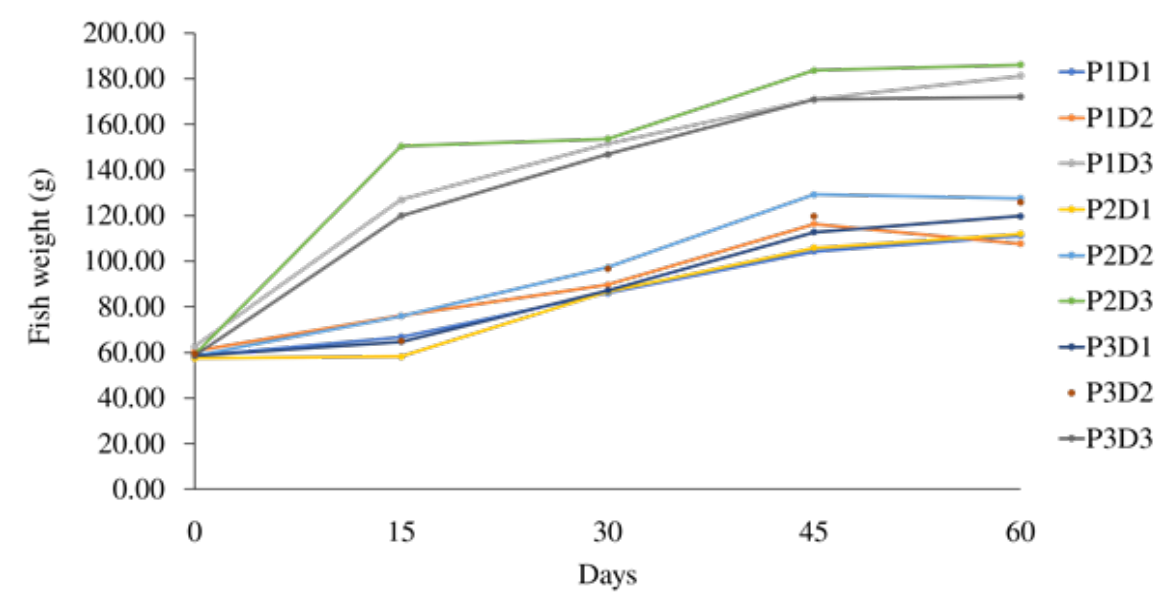

Figure 6. The increased weight during 60 days of botia fish rearing. Note: * P1D1: the particle size was $1 \mathrm{~mm}$ and the dose was $1.4 \mathrm{~g} / \mathrm{L}$; P1D2: the particle size was $1 \mathrm{~mm}$ and the dose was $1.8 \mathrm{~g} / \mathrm{L}$; P1D3: the particle size was 1 $\mathrm{mm}$ and the dose was $2.2 \mathrm{~g} / \mathrm{L}$; P2D1: the particle size was $2 \mathrm{~mm}$ and the dose was $1.4 \mathrm{~g} / \mathrm{L}$; P2D2: the particle size was $2 \mathrm{~mm}$ and the dose was $1.8 \mathrm{~g} / \mathrm{L}$; P2D3: the particle size was $2 \mathrm{~mm}$ and the dose was $2.2 \mathrm{~g} / \mathrm{L}$; P3D1: the particle size was $3 \mathrm{~mm}$ and the dose was $1.4 \mathrm{~g} / \mathrm{L}$; P3D2: the particle size was $3 \mathrm{~mm}$ and the dose was $1.8 \mathrm{~g} / \mathrm{L}$; P3D3: the particle size was $3 \mathrm{~mm}$ and the dose was $2.2 \mathrm{~g} / \mathrm{L}$.

\section{Fish production performance}

Fish production performance during this study showed increased length and weight for 60 days rearing. The data of increased length and weight of botia fish showed in Figure 6 and Figure 7 below.

According to Figure 6 and Figure 7, the fish weight and length were increased until the end of the study. The increased growth of botia fish that was reared in filtration media added with blood clam shell (in certain size and dose) containing $\mathrm{CaCO}_{3}$, showed a certain mechanism and reaction in water that capable to establish an environment for fish growth and fish survival.The mineral contained in blood clam shell can be utilized by fish for bone mineralization process (Liang et al.,2018), and Meilisza et al. (2011) stated that fish can absorb directly calcium and magnesium form water or feed.

The production performance of botia fish includes SR, GR, and FCR. In SR parameter, it showed that there was an interaction between the particle size and the dose of blood clam shell. Meanwhile, in GR and FCR parameter were not showed any interaction between the particle size and the dose of blood clam shell. Yet, 


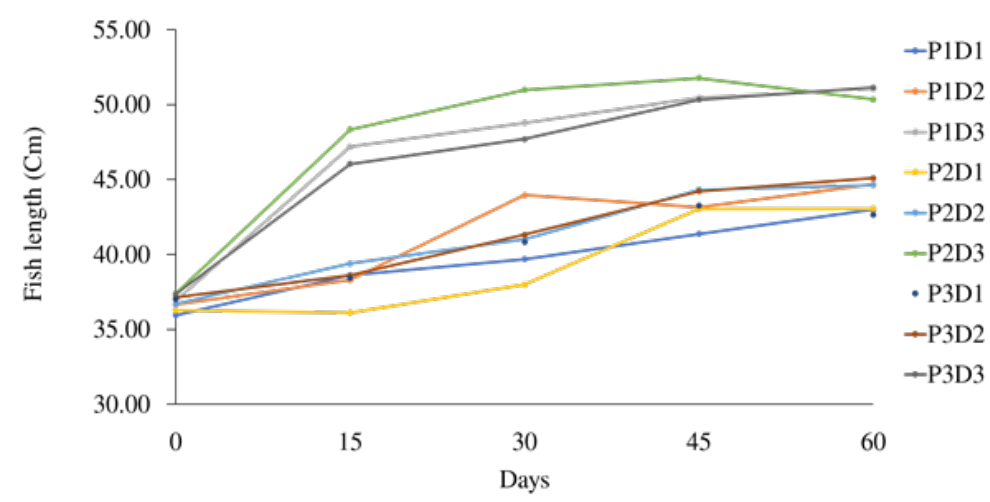

Figure 7. The increased length during 60 days of botia fish rearing. Note: * P1D1: the particle size was $1 \mathrm{~mm}$ and the dose was $1.4 \mathrm{~g} / \mathrm{L}$; P1D2: the particle size was $1 \mathrm{~mm}$ and the dose was $1.8 \mathrm{~g} / \mathrm{L}$; P1D3: the particle size was 1 $\mathrm{mm}$ and the dose was $2.2 \mathrm{~g} / \mathrm{L}$; P2D1: the particle size was $2 \mathrm{~mm}$ and the dose was $1.4 \mathrm{~g} / \mathrm{L}$; P2D2: the particle size was $2 \mathrm{~mm}$ and the dose was $1.8 \mathrm{~g} / \mathrm{L}$; P2D3: the particle size was $2 \mathrm{~mm}$ and the dose was $2.2 \mathrm{~g} / \mathrm{L}$; P3D1: the particle size was $3 \mathrm{~mm}$ and the dose was $1.4 \mathrm{~g} / \mathrm{L}$; P3D2: the particle size was $3 \mathrm{~mm}$ and the dose was $1.8 \mathrm{~g} / \mathrm{L}$; P3D3: the particle size was $3 \mathrm{~mm}$ and the dose was $2.2 \mathrm{~g} / \mathrm{L}$

according to treatment with dose of $2.2 \mathrm{~g} / \mathrm{L}$ was found significantly different result especially in treatment P1D3, P2D3, and P3D3 as showed in Table 4 below.

The different within SR was caused by the interaction between the particle size and dose of blood clam shell. Furthermore, the SR parameter resulted during botia fish rearing was showed higher value by $84,03-100 \%$. This value was higher than previous study done by Ghofur and Harianto (2018). Yet, the value of GR and FCR parameters was only caused by the different dose of blood clam shell.

Fish growth is affected by internal and external factor. This study indicated the effect of external factor associated with the environment (physical, chemical, and biological) (Hidayat et al., 2013). The external factor resulting from the increased of $\mathrm{CaCO}_{3}$ compound in water showed significantly different result in chemical quality of water. Furthermore, this result affected fish appetite that could improve fish weight and length. An optimal environment could support metabolism process, therefore, it could maintain fish appetite and fish physiology condition for avoiding stress and increasing fish survival rate. NRC (2011); Liang et al., (2018) stated that fish is capable to absorb the calcium whether from fish feed or from water for their growth.

\section{CONCLUSION}

The addition of blood clam shell by $2.2 \mathrm{~g} / \mathrm{L}$ as media filtration affected fish survival rate, fish growth, and feed conversion ratio.

\section{ACKNOWLEDGEMENT}

Appreciation and thanks to Directorate Research and Community Service, DirectorateGeneral of Research and Development, Ministry of Research, Technology, and Higher Education, according to assignation of Research Implementation for fiscal year 2019. This research is fully funded by the program of Penelitian Tesis Megister Nomor Kontrak: 3/E1/KP.PTNBH/2019.

\section{REFERENCES}

Ardi I, Setiadi E, Kristanto AH, Widiyati A. 2016. Salinitas optimal untuk pendederan benih ikan betutu Oxyeleotris marmorata. Jurnal Riset Akuakultur 11: 339-347.

Aslamyah S, Karim MY, Badraeni, Tahya AM. 2018. Effect of fermented seaweed addition on blood glucose level, hepatosomatic index, and gastric evacuation rate of milkfish, Chanos chanoslarvae. ACL Bioflux 11: 226-231.

Bartonkova J, Hyrsl P, Vojtek L. 2016. Glucose determination in fish plasma by two different 
moderate methods. Masaryk University, Faculty of Science, Institute of Experimental Biology, Brno, Czech Republic. ACTA VET BRNO 85: 349-353.

Bragnballe J. 2015. A Guide to: Recirculation Aquaculture: an Introduction to the New Environmentally Friendly and Highly Productive Closed Fish Farming Systems. Denmark (DK): FAO and EUROFISH. Bab dalam Buku publ.

BRBIH. 2010. Pembenihan Ikan Botia Chromobotia macracanthus Blekeer Skala Laboratorium. BRBIH. Depok, Jawa Barat. Bab dalam Buku

Deswati, Febriani N, Pardi H, Yusuf Y, Suryani H. 2018. Applications of aquaponics on pakcoy Brassica rapa $\mathrm{L}$ and nila fish Oreochromis niloticus to the concentration of ammonia, nitrite and nitrate. Riental Journal of Chemistry 34: 2447-2455.

Devi PA, Padmavathy P, Aruljothi ASK. 2017. Review on water quality parameters in freshwater cage fish culture. International Journal of Applied Research 3: 114-120.

Eames SC, Philipson LH, Prince VE, Kinkel MD. 2010. Blood sugar measurement in zebrafish reveals dynamics of glucose homeostasis. Journal Zebrafish 7: 205-213.

[EKI] Ekologi Kelautan Indonesia. 2017. Ekonomi Ikan Hias Indonesia. Wahana Riset Mandiri Ekonomi Kelautan Indonesia. Data Suhana. [Internet] [diunduh 11 Oktober 2019]. Tersedia pada: http://Suhana.web.id. [11 Juni 2020].

Ghofur M, Harianto E. 2018. Kinerja produksi ikan botia Chromobotia macracanthus padat tebar tinggi dengan sistem resirkulasi. Jurnal Akuakultur Sungai dan Danau 3: 17-25.

Goddard S. 1996. Feed Management in Intensive Aquaculture. New York (US): Chapman and Hall.

HidayatD, Ade. DS, Yulisma. 2013. Kelangsungan hidup, pertumbuhan danefesiensi pakan ikan gabus Channa striata yang diberi pakan berbahan baku tepung keong mas Pomacea sp.. Jurnal Akuakultur Rawa Indonesia 1: 161-172.

Iriany, Anugerah A. 2015. Pemanfaatan limbah cangkang kerang bulu sebagai adsorben untuk menjerap logam kadmium (Ii) dan timbal (Ii). Jurnal Teknik Kimia 4: 40-45.
Jubaedah D, Marsi, Rizki RR. 2017. Ultilization of Aanadara granosa as a liming materials for swamp fish ponds for pangasius sp. culture. Journal Aquaculrtura Indonesiana 18: 48-54.

Kadarini T, Musthofa SZ, Subandiyah S, Priono B. 2015. The effect of $\mathrm{CaCO}_{3}$ addition in rearing media on Kurumoi rainbow fish Melanotaenia parva productivity. Jurnal Riset Akuakultur 10: 187-197.

Kottelat M. 2013. The fishes of the inland waters of Southeast Asia: A Catalogue and core bibliography of the fishes known to occur in freshwaters, mangroves and estuaries. Raffles Bulletin of Zoology 27: 1-663.

Liang H, Mi H, Ji K, Ge X, Ren X, Xie J. 2018. Effects of dietary calcium levels on growth performance, blood biochemistry and whole body composition in juvenile bighead carp Aristichthys nobilis. Turkish Journal of Fisheries and Aquatic Sciences 18: 623-631.

[LIPI] Lembaga Ilmu Pengetahuan Indonesia. 2014. Kualitas air kota besar Indonesia memburuk. http://lipi.go.id/berita/single/ LIPI.-Kualitas-Air-Kota-Besar-IndonesiaMemburuk/9280. [Diakses 12 Februari 2020].

Meilisza N, Hirnawati R, Rohmy S, Priyadi A, Slembrouck J. 2011. The utilization of the kinds of live food on clown loach Fish juveniles Chromobotia macracanthus (Bleeker). Institute De Recherche Pour Le Developpment, France c/o Indonesia, Depok. Bab dalam Buku

[NRC] National Research Council. 1977. Nutrient Requirement of Warmwater Fishes and Shelfishes Revised Edition. Washinton DC (US): National Academy Press. pp 102.

[NRC] National Research Council. 2011. Nutrient Requirement of Fish and Shrimp. Washington, DC: National Academy Press.

Nurhidayat, Nirmala K, Djokosetyanto. 2012. Biofilter performance effectiveness on water quality, growth performance and survival rate improvement of red rainbow fish Glossolepis incisus Weber reared in recycled water system. Jurnal Riset Akuakultur 7: 279-292.

Permana A, Kusumah RV, Priyadi A. 2011. Budidaya sebagai model konservasi ex-situ ikan hias botia Chromobotia macracanthus Bleeker). [[Prosiding] Forum Nasional]. Balai Riset Budidaya Ikan Hias, Depok.

Polakof S, Soengas JL, Panserat S, Moon T. 
2012. Glucose metabolism in fish: A review. Journal of Comparative Physiology B 182: 1015-1045.

Priyadi A, Permana A, Nurhidayat. 2013. Clown loach Chromobotia macracanthus mass production improvement through stocking density and water level approach. Jurnal Akuakultur Indonesia 8: 65-75.

Sarkar, Dhikari S, Tiwaril PK. 2018. Importance of Soil and Water Quality Management in Freshwater Aquaculture with Special Reference to Catfish Farmings. Odisha, India: ICAR- Central Institute of Freshwater Aquaculture Kausalyaganga, Bhubaneswar.

Slembrouck J, Priyadi A, Permana A, Ginanjar R, Baras E, Satyani D, Sudarto, Pouyaud L, Legendre M. 2012. Biology and culture of the clown loach Chromobotia macracanthus 2-Importance of water movement and temperature during egg incubation. Aquatic Living Resources 25: 109-118.

[SNI] Standar Nasional Indonesia. 2013. Ikan hias botia Botia spp.-Syarat mutu dan penanganan. Badan Standar Nasional Indonesia. SNI 7843. Suwandi R, Nugraha R, Novila W. 2012. Application of white pulp guava leaf extract Psidium guajava var. pyrifera in transportation of tilapia Oreochromis niloticus. Jurnal Pengolahan Hasil Perikanan Indonesia 15: 252-260.

Yusuf W, Zahra, Hanafi. 2016. Optimasi filter cangkang kerang darah Anadara granosa untuk meningkatkan $\mathrm{pH}$ air gambut. Jurnal Teknologi Lingkungan Lahan Basah 4: 1-10. 